\author{
Katarzyna Drąg \\ Uniwersytet Papieski Jana Pawła II w Krakowie \\ ORCID: 0000-0001-9920-3526
}

\title{
Wartość dobrego słowa w kompetencjach komunikacyjnych
}

\begin{abstract}
Streszczenie
W artykule podjęto próbę określenia tych części składouych kompetencji komunikacyjnych, które dają szansę na eliminowanie przemocy z aktów komunikacji. Zwrócono uwagę na moc słowa jako nośnika dobra lub zła. Troska o obecność dobrych słów u dyskursie publicznym jest jednocześnie szansą na zminimalizowanie przestrzeni przemocy u komunikowaniu. Właściwie rozumiana stosowność komunikacji wyprowadzona z niezbywalnej zasady szacunku dla człowieka jako podmiotu procesu porozumiewania się może stanowić antidotum na przemoc w relacjach komunikacyjnych.
\end{abstract}

Słowa kluczowe: kompetencje komunikacyjne, dobre słowo, etyka komunikacji, przeciudziałanie przemocy w komunikacji

\section{The value of a good word in communication competences}

\begin{abstract}
The article attempts to identify those components of communicative competence that give a chance to eliminate violence from communication acts. Attention was paid to the power of words as a carrier of good or evil. Concern for the presence of good words in public discourse is at the same time an opportunity to minimize the space of violence in communication. Properly understood appropriateness of communication derived from the inalienable principle of respect for human being as the subject of the communication process can be an antidote to violence in communication relations.
\end{abstract}

Keywords: communication skills, good word, communication ethics, counteracting violence in communication.

Postulat zdobywania i poszerzania kompetencji komunikacyjnych jest oczywisty. Komunikowanie jest procesem nieodwracalnym, w związku z tym nie jest możliwe „beztroskie” formułowanie komunikatów, bez brania pod uwagę konsekwencji społecznych ich nadawania. Każdy komunikat niesie ze sobą określone skutki. Podstawowym budulcem naszych komunikatów, suoistym narzędziem, są słowa - nośniki dobra lub zła. Warto zauważyć, że to właśnie warstua werbalna kontaktów międzyludzkich jest 
przestrzenią, w której zachodzić może pieruszy etap przemocy. Użyte przez uczestników komunikowania sformułouania mogą stać się narzędziem przemocy. Troska o jakość słów jest realizacją powinności o charakterze aksjologicznym. Poczynione analizy są próbą spojrzenia na niektóre językowe aspekty aksjologicznej problematyki komunikowania społecznego w kontekście kompetencji komunikacyjnych. Staramy się - z perspektyuy aksjologii komunikowania, a także z perspektywy semiologicznej i perspektyuy lingwistyki komunikowania - odpowiedzieć na pytanie, jaką rolę odgrywają dobre słowa w kompetencjach komunikacyjnych, rozumianych jako „znajomość oraz umiejętność stosowania przez jednostki występujące w roli nadawcy lub odbiorcy środków komunikowania (werbalnych i niewerbalnych, a także technicznych), we wszystkich typach i rodzajach komunikowania". Nie będziemy się zasadniczo zajmowali analizą materialnej strony języka, ale raczej jego formalnymi aspektami, pokazując niektóre tendencje kulturowo-komunikacyjne, odzwierciedlające jakość współczesnych kompetencji komunikacyjnych z perspektywy językowego komunikowania wartości.

Komunikowanie interpersonalne i społeczne posługuje się językiem jako nośnikiem treści. Język jest narzędziem komunikacji, ale jednocześnie język jako system kodów jest koniecznym elementem struktury komunikacyjnej, natomiast sprawność posługiwania się językiem jako nośnikiem wartości jest elementem i wyznacznikiem kompetencji komunikacyjnych. Co więcej, język jest nie tylko nośnikiem określonych wartości, lecz także sam stanowi wartość, analogicznie do ducha McLuhanowskiego formalizmu medialnego, że medium is the message ${ }^{2}$.

Każdy język, rozumiany szerzej niż tylko system znaków służących jako narzędzie informacji i komunikacji, ale jako zjawisko kulturowe, jako część kultury, będącej duchowym dorobkiem człowieka, jest wartością. Kultura językowa, ta materialna i duchowa, jest tym obszarem, u którym szczególnie wyraźnie manifestują się wartości. Żaden człowiek oraz żadna społeczność nie mogą żyć ani rozwijać się, ani urzeczywistniać samych siebie, nie realizując równocześnie i nie uczestnicząc w wartościach. To uczestniczenie $w$ wartościach $w$ świecie mediów dane nam jest $w$ dużej mierze poprzez język. W takim ujęciu język nie jest tylko narzędziem, nośnikiem wartości, ale sam jest wartością. Pojęcie wartości i wartościowania przenosi nas u sposób naturalny w obszar aksjologii i etyki komunikacji.

Podstawowym wymiarem mediów jest komunikacja wartości, która się dokonuje zausze $w$ perspektywie określonych, świadomych lub nieświadomych powinności i celów, ukrytych w słowach i języku³. Słowa mają wielką moc. Choć popularnym jest związek frazeologiczny: „to tylko słowa”, który wskazuje na brak przełożenia słów na konkretne reakcje i pozostawanie w sferze planów, to jednak w rzeczywistości

\footnotetext{
${ }^{1}$ L. Słupek, R. Bartoszcze, Kompetencja komunikacyjna [w:] Słownik terminologii medialnej, red. W. Pisarek, TAiWPN Universitas, Kraków 2008, s. 98.

2 Por. M. McLuhan, Zrozumieć media. Przedłużenia człowieka, przeł. N. Szczucka. Wydawnictwa Naukowo-Techniczne, Warszawa 2004, s. 37n.

${ }^{3}$ Por. M. Drożdż, Język nienawiści $w$ dyskursie medialnym, „Acta Universitatis Lodziensis. Folia Litteraria Polonica” 2016, nr 1(31), s. 21-22, http://dx.doi.org/10.18778/1505-9057.31.02.
} 
moc słowa jest nie do przecenienia. Teoria aktów mouy przyniosła opis tej właśnie mocy słowa i uporządkowała to zagadnienie w kilku kategoriach. Performatyuność komunikowania przypomina o tym, jakie „przełożenie” na życie, działanie, rzeczywistość może mieć użycie konkretnych słów w konkretnych kontekstach ${ }^{4}$.

Performatywny charakter języka wskazuje jeszcze bardziej na korelację między językiem a etyką. Wiele słów, w określonych sytuacjach i uwarunkowaniach, implikuje zobowiązania i rodzi powinności etyczne. Fakt ich wypowiedzenia tworzy powinność, na przykład wóuczas, gdy mówię „obiecuję”, „przyrzekam”, „ślubuję”, nakładam na siebie moralny obowiązek dotrzymania danego słowa. Powinnościowy charakter mają jednak nie tylko performatywy uyraźne. Gdy mówię na przykład „zrobię to” czy „zajmę się tym”, róunież biorę na siebie odpowiedzialność za działanie, którego się podejmuję. „Dlatego właśnie możemy powiedzieć, że zobowiązujący charakter wypowiadanych przez nas słów wynika nie tyle z ich znaczenia (móuiąc „obiecuję, że cię zabiję", nie obiecuję, ale grożę), ile z ułasności języka, jaką jest performatyuność, czyli zdolność do zmieniania rzeczywistości" ${ }^{\text {. Ta }}$ zdolność ma nie tylko pozytywny aspekt, ale, niestety, rodzi wiele negatywnych skutków. Słowem można zniszczyć i zbudować. Za pomocą słów można godzić w godność człowieka, naruszać dobre imię, prywatność, rzucać oszczerstwa, plotkować, manipulować, kłamać czy nękać na różne sposoby. Szczególnymi przejawami przemocy, które opierają się na komunikowaniu bez kontaktu osobistego, są choćby niektóre przykłady cyberprzemocy (ang. cyberbulling), uśród których wyróżnia się między innymi flaming, zastraszanie on-line, cyberstalking, dyskredytację, podszywanie się pod $\operatorname{kogoś}^{6}$. Cyberprzemoc polega zasadniczo na przesyłaniu komunikatów werbalnych, a jej zastraszające skutki śuiadczą o dobrej lub złej mocy słów.

W tym kontekście warto spróbować postawić tezę, że słowem także można zatrzymywać falę przemocy, umniejszać przemoc. Podjęcie trudu troski o dobre słowo może pomóc w burzeniu murów niechęci i konfliktów. Zażegnywanie kryzysów komunikacyjnych i naprawa ewentualnych skutków negatywnych komunikatów również ma szansę zaistnieć dzięki dobrym słowom.

Wymaga kilku słów wyjaśnienia użyte w tytule określenie „dobre słowo”. Słowo podlegać może ocenie jakościouej. Jest ono waloryzowane. Określenie „dobre” przenosi nas w sferę etyki. Etyka słowa to sformułowanie ugruntowane naukowo? Zagadnienia związane z etyką słowa pozostają w zainteresowaniu choćby Komisji Etyki Słowa przy Radzie Języka Polskiego kierowanej przez Jadwigę Puzyninę. „Ustawa o języku polskim z roku 1999 nakłada na Radę Języka Polskiego obowiązek opiniowania

\footnotetext{
${ }_{4}^{4}$ Por. np. R. Przybylska, Wstęp do nauki o języku polskim, Wydawnictwo Literackie, Kraków 2003, s. 24.

${ }^{5}$ K. Rozmarynouska, Performatywność języka a powinność moralna, „Studia Philosophiae Christianae" 2018, t. 54, nr 2, s. 145.

${ }^{6}$ Por. V. Lubkina, G. Marzano, Cyberprzemoc [w:] Zagrożenia cyberprzestrzeni, red. J. Lizut, Wydawnictuo Wyższej Szkoły Pedagogicznej im. Janusza Korczaka, Warszawa 2014, s. 85-98. ${ }^{7}$ Por. np. A. Cegieła, Stowa i ludzie. Wprowadzenie do etyki słowa, Dom Wydawniczy Elipsa, Warszawa 2014.
} 
sposobu używania języka polskiego w ogóle, a w szczególności („w drodze uchwały”), „używania języka polskiego u działalności publicznej”. Oznacza to wyjście na szerszy teren dyskursu. Przyjmuję więc rozumienie przez etykę słowa etyki mowy, tj. etyki komunikacji językowej, etyki dyskursu - pisał Jerzy Bartmiński, charakteryzując kompetencje i zadania Rady ${ }^{8}$.

Określenie „dobre słowa” oznacza, że oceniamy słowa z perspektyuy etycznej, wartościujemy ze uzględu na dobro. Celem etyki jest dobro, a dobrem jest to, co chroni wartość i godność człowieka. Każdy rodzaj przemocy narusza godność, będącej obiektem przemocy, osoby, a więc każde dobre słowo może być antidotum na przemoc. Stąd wynika postulat propagowania wartości dobrych słów jako remedium na przemoc.

We uspółczesnym zmediatyzowanym społeczeństwie nie podlega dyskusji potrzeba kształcenia kompetencji komunikacyjnych. Często jednak kompetencje te zdają się być utożsamiane z umiejętnością skutecznego komunikowania się. Takie pojmowanie kompetencji komunikacyjnych może przeakcentowywać rolę warsztatu komunikacyjnego i efektywność perswazyjności. Rozwijanie umiejętności komunikacyjnych to kształtowanie równomiernie sprawności dotyczących formy komunikowania i rozumienia roli treści. Można zasugerować twierdzenie, że rozwój wyłącznie sprawności w zakresie skutecznego osiągania celów komunikacyjnych, z pominięciem głębokiej refleksji nad treścią komunikatów, jakością używanych słów, wartością etyczną słowa, może doprowadzić do sytuacji, w której u sposób komunikacyjnie sprawny nadawca krzyudzi odbiorcę, stosując przemoc w różnych jej formach. Często słowo przemoc kojarzone jest przede uszystkim z czynami, działaniem fizycznym, jednak przemoc słouna może być róunie dotkliwa i destrukcyjna.

Mądry rozwój kompetencji komunikacyjnych, który dokonuje się przez całe życie, a szczególnie intensywnie powinien następować w wieku młodzieńczym, powinien być poprzedzony zrozumieniem podstawowych kuestii: skuteczność komunikowania, efektywność działań perswazyjnych musi iść w parze ze zuróceniem uwagi na podmiotowość osób, z którymi się komunikujemy. Jakość przekazywanych treści jest integralną częścią kompetencji komunikacyjnej. Kompetencja ta dotyczy obszaru etyczności, gdyż uczestnikiem procesu komunikowania jest osoba, która ma wartość, godność i przynależne dobra osobiste.

Taka perspektywa kształtowania kompetencji komunikacyjnych w ramach edukacji medialnej daje szansę na ułaściue rozumienie kategorii skuteczności i stosouności komunikowania. Stosowność komunikowania, która przejawia się między innymi w unikaniu agresji, musi mieć jakąś głęboką motywację. „Stosouność ma róunież

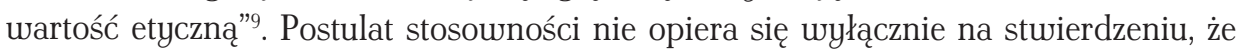
„wolno” zachować się językowo w określony sposób, a „nie wolno” w inny. Jakie argumenty przemawiają za utrzymywaniem zasad savoir-vivre'u? Wykluczeniem przemocy

\footnotetext{
${ }^{8}$ J. Bartmiński, Etyka słowa a potoczny wzorzec komunikacji, http://wuw.rjp.pan.pl/index. php?option=com_content\&view=article\&id=1352\&Itemid=50 (dostęp: 10.07.2019).

${ }_{9}$ K. Marcyński, Kompetencja komunikacyjna. Studium medioznawcze, Wydaunictuo Naukowe Uniwersytetu Kardynała Stefana Wyszyńskiego, Warszawa 2017, s. 179.
} 
z przestrzeni komunikowania? Rozumienie głębokich motywów tej części składowej kompetencji komunikacyjnej daje szansę na stosowanie w praktyce komunikacyjnej dobrych słów. Tym podstawouym i niezbywalnym argumentem jest szacunek dla godności osoby, z którą się porozumiewamy. „Podstawą etyki słowa jest podmiotowe, a nie instrumentalne traktowanie się partnerów dialogu, to znaczy wzajemne szanowanie się, uwzględnianie swoich poglądów, przyzuyczajeń itd." ${ }^{\text {. }}$

Rozwijanie tej sfery kompetencji komunikacyjnych u uczestników aktów komunikowania może się opierać na analizie kilku pól zagadnień, które pogrupować można pod tytułami: konteksty dobrego słowa, stop dla słów o negatywnym potencjale, stosowanie dobrych słów, umiejętność radzenia sobie w granicznych sytuacjach komunikacyjnych. Punktem wyjścia do poczynionych refleksji jest przekonanie, że: słowo może być narzędziem przemocy; kształcenie u zakresie komunikowania nie może być ukierunkowane tylko na efektywność persuazyjną, słowem można zahamować przemoc, stworzyć werbalną zaporę przed przemocą i ukształtować przestrzeń komunikacyjną w taki sposób, by zminimalizować potencjalne zagrożenie zaistnienia przemocy.

\section{Konteksty kompetencyjne dobrego słowa}

Punktem wyjścia w budowaniu właściwego kontekstu komunikowania jest zaistnienie: rozumienia i zrozumienia, ważności i uważności oraz słuchania i uysłuchania. Są to warunki wstępne, których spełnienie zwiększa szansę na uniknięcie sytuacji przemocouych podczas komunikacji.

Pieruszym, podstawowym warunkiem kompetentnej komunikacji jest rozumienie i zrozumienie. Rozumienie to faza procesu komunikacyjnego, która jest fundamentem porozumienia. Potwierdzenie właściuego zdekodowania komunikatu przez odbiorcę może zablokować potencjalne zagrożenia przyjmujące postać odrzucenia, dezinformacji, manipulacji. Sprawdzenie, czy adresat komunikatu prawidłowo, czyli zgodnie z intencją nadawcy, odkodował docierającą do niego informację, pozwala upewnić się, czy dalszy kontakt nie będzie budowany świadomie lub nieświadomie na fałszywym fundamencie. Skoro komunikowanie jest porozumiewaniem, to uwaga poświęcona rozumieniu u sensie dekodowania jest szczególnie ważna.

Zrozumienie to odczytanie intencji, otwarcie na nadawcę i treści, które chce przekazać. Chęć rozumienia i zrozumienia nadawcy jest podstawą do wyzbytej z elementów przemocy komunikacji. Zrozumienie polega na tym, że uczestnik jest u stanie zawartą w komunikacie wiadomość uznać za informację, treść komunikatu ma dla niego charakter informatywny i jest w stanie na tę treść odpowiedzieć. Treść zawarta w komunikacie ma sens dla odbiorcy i może na nią sensownie odpowiedzieć. Zrozumienie przekazu od innej osoby pozwala na ocenienie jej racji, argumentów i uniknięcie emocjonalnych

\footnotetext{
${ }^{10}$ A. Markouski, Etyka stowa [w:] H. Jadacka, A. Markouski, D. Zdunkiewicz-Jedynak, Poprawna polszczyzna. Hasta problemowe, Wydawnictwo Naukowe PWN, Warszawa 2008, s. 86.
} 
reakcji, które nie odzwierciedlają treści komunikatu. Zrozumienie umożliwia uniknięcie argumentacji pozamerytorycznej, która niesie ryzyko zachowań przemocouych. Reakcje emocjonalne wynikają często z faktu niezrozumienia tego, co adresaci odbierają. W takiej sytuacji uruchamiane mogą być mechanizmy obronne, które często są oparte na agresji. Założenie: „chcę Cię rozumieć” jest narzędziem przeciudziałania przemocy.

Drugi warunek, którego spełnianie tworzy właściuy kontekst dla dobrych słów, można określić: słuchanie i wysłuchanie. Umiejętność uważnego słuchania, ominięcie barier komunikacyjnych oraz znalezienie czasu na pełne uysłuchanie odbiorcy pozwala zrozumieć właściwą wagę spraw, służy porozumieniu. Taka postawa komunikacyjna jest skuteczną blokadą lekceważenia, które może stać się przyczynkiem do przemocy w komunikacji. Bagatelizowanie przekazu nadawcy, pogarda, która wkracza tam, gdzie nie było słuchania i wysłuchania, uruchamia negatyune emocje. Komunikat: „chcę Cię uysłuchać" daje możliwość uniknięcia konfliktów.

Trzeci warunek można nazwać: ważność nadawcy i uważność odbiorcy. Zuraca on uwagę na funkcję fatyczną w komunikacji. Funkcja ta przejawia się w podtrzymywaniu relacji komunikacyjnych. Polega na uskazywaniu, że ktoś, z kim nawiązuję rozmowę, jest przeze mnie zauważony, dostrzeżony, uznany za ważnego. Funkcja fatyczna realizuje się także podczas truania rozmowy pomiędzy osobami, które się znają. Wtedy funkcja ta pozwala na potwierdzenie, że nadawca słuchany jest uważnie, że odbiorca nadąża za tokiem wywodu. Pokazanie szacunku dla rozmówcy, dowartościowanie relacji pomiędzy uczestnikami procesu komunikowania jest tworzeniem płaszczyzny, na której trudniej o przemoc słowną. Komunikat: ,jesteś ważny” jest sposobem okazania szacunku uczestnikowi komunikowania i może tamować falę ewentualnej przemocy słownej.

Przywołane konteksty są integralną częścią umiejętności porozumiewania się. Ich przyjęcie, stosowanie, a przede uszystkim zrozumienie ich upłyuu na proces komunikowania jest podstawouym orężem $\mathrm{w}$ walce z ewentualną przemocą w komunikacji. Rola słuchania, rozumienia oraz właściuego traktowania odbiorcy i wysyłanego przez niego przekazu jest nie do przecenienia. Nie można kształtować kompetencji komunikacyjnej z pominięciem tych fundamentalnych warunków.

\section{Rugowanie słów o negatywnym potencjale}

Każdy człowiek uczestniczący w komunikowaniu społecznym staje nieustannie w obliczu dokonywania uyborów wartości lub antywartości. Wynika to z faktu, że przestrzeń komunikowania społecznego nie jest niczym innym, jak wielkim areopagiem wymiany dóbr i wielką przestrzenią komunikowania bardzo różnych wartości. Przeważnie są to wartości preferowane na podstawie dominujących w określonym miejscu i czasie tendencji kulturowo-medialnych i cywilizacyjnych, komercjalizacji, globalizacji, ideologizacji, umasowienia kultury, popularyzacji kultury itp. Konkretne wybory i działania człowieka, realizowane w konkretnej przestrzeni komunikowanych medialnie wartości, nie tylko wpływają na aktualne wymiary samostanowienia, 
samopanowania i urzeczywistniania się jego człowieczeństua, lecz także rzutują na kształtowanie się jego postaw moralnych w przyszłości ${ }^{11}$.

Działanie człouieka nie jest działaniem u próżni, ale zausze jest zuiązane albo z dobrem moralnym, albo ze złem. Przestrzeń komunikacji społecznej jest przestrzenią wielorakich ludzkich decyzji, wyborów i działań - dobrych lub złych. To człowiek-osoba jest podmiotem wartości moralnych. To on dokonuje obiektywizacji wartości, która dokonuje się w dużej mierze poprzez język i jego struktury ${ }^{12}$.

W czasie pielgrzymki do Polski w 1991 roku Jan Paweł II mówił o potrzebie troski o słowo, które daje początek czynom. Podstawową etyczną powinnością człowieka jest „szczególna odpowiedzialność za słowa, które się wypowiada, bo one mają moc świadectua, albo świadczą o praudzie, albo są dla człowieka dobrem, albo też nie świadczą o praudzie, są jej zaprzeczeniem i utedy są dla człowieka złem"13. Słowa, które nie świadczą o prawdzie i nie szanują godności człowieka, mają destrukcyjny charakter. Troszcząc się o rozwój kompetencji komunikacyjnych, należy uskazać i uświadomić destrukcyjny charakter słów, które bezsprzecznie negatyunie upływają na proces porozumiewania się. Katalog przykładów takich zachowań werbalnych, które mają jednoznacznie negatyuny potencjał, należy rozpocząć od słów negatyunej oceny osoby.

Wielu sytuacji wystąpienia przemocy w komunikowaniu można by uniknąć, gdyby wykluczyć słowa oceniające bezpośrednio człowieka, a nie jego działania. Taka ocena, wystosowanie komunikatu zawierającego opinię etykietującą uczestnika komunikacji, już jest przemocą. Nazwanie kogoś na przykład kłamcą, w odróżnieniu od oceny jego słów jako kłamliwych, jest przemocą słowną. Stawia uczestnika komunikacji w sytuacji bardzo trudnej, przysparza bólu, powoduje stres i chęć obrony. „Celem przemocy jest wyrządzenie ofierze szkody, wywołanie bólu, zadanie cierpienia, poniżenie” ${ }^{14}$. Używanie słów negatyunie oceniających osobę doprowadza do realizacji takiego celu i jest przemocą.

Słowa o negatywnym potencjale przyjmujące formę oceny człowieka wynikać mogą z różnych przyczyn: chęci zaatakowania przeciunika, braku rozróżnienia między argumentem ad rem i ad personam, wysokim stopniem rozemocjonowania, ale mogą też być wywołane poprzez niewłaściwie zadane pytanie, które staje się zachętą do oceny człowieka, a nie jego decyzji. Tu należy uspomnieć choćby o odpouiedzialności dziennikarzy, którzy formułują pytania i animują dyskusję. Suoimi wypowiedziami mogą „naprowadzać” rozmówcóu na tory właściwej lub pełnej przemocy rozmowy.

${ }_{11}$ Por. M. Drożdż, Osoba i media. Personalistyczny paradygmat etyki mediów, Wydaunictwo Diecezji Tarnouskiej Biblos, Tarnów 2005, s. 423.

12 Por. M. Drożdż, Język nienawiści $w$ dyskursie medialnym, „Acta Universitatis Lodziensis. Folia Litteraria Polonica” 2016, nr 1(31), s. 21-22, http://dx.doi.org/10.18778/1505-9057.31.02.

13 Jan Paweł II, Homilia wygłoszona w czasie Mszy św. w Olsztynie, 6 czerwca 1991 roku [w:] Jan Paweł II, Pielgrzymki do Ojczyzny. Przemówienia i homilie, wyd. 3, Społeczny Instytut Wydawniczy Znak, Kraków 2005, s. 669.

14 W. Jedlecka, J. Helios, Współczesne oblicza przemocy. Zagadnienia wybrane, E-Wydawnictwo. Prawnicza i Ekonomiczna Biblioteka Cyfrowa, Wrocław 2017, s. 8. 
Zasadniczą treścią wiedzy o komunikowaniu i umiejętności komunikacyjnych winno być stuierdzenie, że ocena etyczności człowieka pozostaje poza zasięgiem rozmóuców, jako uczestnicy aktu komunikowania w żadnej sytuacji nie jesteśmy do takich ocen uprawnieni.

Słowami o negatywnym potencjale są oczywiście wulgaryzmy i przekleństwa, uszelkie sformułowania, które są uznane u danym społeczeństwie za ordynarne i nieprzyzwoite. Niekiedy negatywne słowa są określane nieco archaicznym mianem „obsceniczne”. Tak określa negatyune słowa choćby Kodeks Etyki Dziennikarskiej Stowarzyszenia Dziennikarzy Polskich w punkcie 13, który brzmi: „Język wypowiedzi powinien być staranny, należy unikać uulgaryzmów i określeń obscenicznych"15.

Szczególnie destrukcyjne dla porozumienia oraz stanowiące przemoc są w komunikowaniu kłamstwa, oszczerstwa, obmowy, plotki. Wszystkie słowa służące dezinformacji, wprowadzeniu do obiegu informacyjnego nieprawdy uderzają w odbiorców, których dotyczą. Krzyudzą i odbierają poczucie godności. Kłamstuo jest próbą zdobycia przeuagi nad słabszym, bo często nieświadomym przeciunikiem w komunikacji. Usunięcie z przekazu kłamstua i jego konsekwencji jest zazwyczaj możliwe tylko częściowo. „Etyka słowa jest jednym z warunków tego, co nazywa się powodzeniem, fortunnością aktu mowy. Zasadza się ona na naturalnym oczekiwaniu odbiorcy tekstu, że ten, kto mówi (pisze) jest prawdomówny, nie oszukuje"16. Manipulacja, deziformacja, fake newsy uderzają w godność uczestników komunikowania. „Odpowiedzialność za prawdę utruala podmiotową sprawczość osoby i osadza ją w perspektywie aksjologii, w której »informacja prawdziwa« i »przekazana w prawdzie« ma swoją nieocenioną wartość, również etyczną" ${ }^{17}$. Skuteczność komunikacyjna, efektywność w osiąganiu celów komunikowania nie może nigdy być oparta na słowach kłamliwych. Skuteczność osiągnięta takimi metodami nie jest w żadnej mierze przejawem kompetencji komunikacyjnej. We właściwie rozumianej kompetencji skuteczność i stosowność komunikowania idą w parze.

Negatyuny potencjał wnoszą do aktu komunikowania także uszelkie słowa, które służą uprzedmiotowieniu człowieka. Pejoratyunym przykładem może być tu słownictwo ośmieszające rozmóucę, słowa szyderstua, kpiny i wszelkich form „używania” osoby jako przedmiotu gry słounej. Takie zachowania językoue uprost określić należy stosowaniem przemocy. Podobnie jak słowa obrażające, którą mają na celu sprawianie komuś przykrości i krzyudy.

Etyka słowa zobowiązuje uczestników komunikacji językowej do zachowań mających na uwadze nie tylko własne cele, ale też prawa i potrzeby drugiego człowieka. Nadawca ma prawo do szczerości w wyrażaniu swoich poglądów, a odbiorca ma prawo do suobody w uyborze postawy światopoglądowej. Naganne jest czynienie

${ }^{15}$ Kodeks Etyki Dziennikarskiej SDP, http://sdp.pl/s/kodeks-etyki-dziennikarskiej-sdp (dostęp: 10.07.2019).

16 A. Markouski, Etyka stowa, op. cit., s. 85.

${ }^{17}$ M. Drożdż, Osoba i media w prawdzie i uczciwości, Wydaunictuo Petrus, Kraków 2018, s. 108 . 
ze słów narzędzia zła, czyli na przykład zastraszanie odbiorcy, obrzucanie go obelgami, przekleństwami, wykpiwanie, szydzenie z niego, naigrywanie się ${ }^{18}$.

\section{Używanie słów o pozyływnym potencjale}

W przestrzeni komunikacyjnej wypełnionej dobrymi słowami brakuje miejsca na przemoc. Słowa, które tworzą klimat szacunku, odbierają przestrzeń przemocy. Można spróbować stworzyć katalog zachowań komunikacyjnych, które sprzyjają pozytywnym relacjom między uczestnikami i jednocześnie stanowią oręże przeciu przemocy. Ich używanie przyczynia się do minimalizowania szans na wystąpienie kryzysowych, przemocowych sytuacji komunikacyjnych. Wymienić tu należy choćby: słowa, które są wyrazem szacunku wobec rozmóucy. Szacunek ten ma zuiązek z faktem, że rozmóuca jest podmiotem komunikacji, osobą. Okazanie szacunku nie musi być róunoznaczne ze zgadzaniem się z nim i jego przekonaniami. Wzajemne wyrażenie szacunku dla podmiotów komunikowania, tylko dlatego, że są podmiotami i mają w zuiązku z tym prawo do poważania, może skutkować pozbawieniem potencjalnej przemocy siły napędowej.

Dowartościowanie rozmóucy, ewentualne słowa pochwały wobec podejmowanych wysiłków róunież nie muszą być równoznaczne z przyjęciem poglądów odbiorcy. Słowa takie mogą służyć przezuyciężaniu negatywnego nastawienia, wytrącać narzędzia przemocy z ręki uczestnika komunikowania. Dowartościowanie partnera komunikacji, zułaszcza w jego osobowej godności, jest dobrą strategią na przykład w relacjach nauczyciel-uczeń i stanowi właściuy punkt wyjścia pod przyszłe efekty edukacyjno-wychowawcze.

Nieodzownym elementem kompetencji komunikacyjnej jest także umiejętność używania słów, które umożliwiają naprawę naruszonych relacji między odbiorcą i nadaucą. Jest to umiejętność autorefleksji, analizy dotychczasowego przebiegu porozumiewania i uyciągnięcia uniosków. Słowa przeprosin i wyjaśnień - co oczywiste - odbierają przestrzeń potencjalnej przemocy.

Podobnie rzecz ma się ze słownictuem wyrażającym udzięczność, empatię i pozytywne emocje. Oczywiście nie w każdych warunkach i w stosunku do każdego odbiorcy chcemy wyrażać pozytywne emocje. Kompetentny komunikator odróżnia jednak poziom emocjonalny (lubię kogoś lub nie lubię) od poziomu szacunku (ten należy się każdemu, niezależnie od sympatii lub antypatii). To jest punkt wart szczególnej uwagi tych, którzy edukują innych i siebie w zakresie umiejętności komunikacyjnych. Zdefiniowanie szacunku i sympatii oraz wyjaśnienie podstaw jednego i drugiego jest jednym z warunków sukcesu komunikacyjnego.

Podobnie podstawowy i użyteczny charakter w walce z przemocą ma rozróżnienie między umiejętnym powiedzeniem prawdy z szacunkiem a krytykanctuem, które stwarza przestrzeń dla przemocy słownej. Właściwe formułowanie słów krytyki to jedna

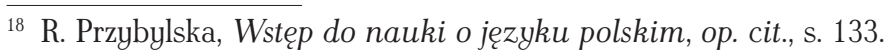


z podstawowych umiejętności u procesie porozumiewania się. Krytyka róunież może być dobrym słowem, ale wyłącznie przy zachowaniu zasady szacunku dla podmiotowości uspółrozmówcy. Jeśli w początkouyych komunikatach pojawia się brak szacunku w postaci na przykład ironii, lekceważącego zurotu do adresata, to można z góry przewidzieć, że komunikat ten będzie przeszkodą w nawiązaniu kontaktu. Uprawniona krytyka możliwa jest zausze na fundamencie elementarnego szacunku dla rozmówcy.

Wymienione zachowania słowne winny wypełniać komunikację międzyludzką. Ich właściue rozumienie i zastosowanie zwiększa szansę na uniknięcie przemocy słownej.

\section{Umiejętność radzenia sobie w granicznych sytuacjach komunikacyjnych}

Kolejnym elementem kompetencji jest umiejętność radzenia sobie $\mathrm{w}$ granicznych sytuacjach komunikacyjnych. Przebieg aktu komunikacyjnego nie zależy tylko od jednej strony. Dlatego kompetentny i świadom wartości dobrych słów uczestnik porozumiewania może zetknąć się z osobą łamiącą zasady stosouności, używającą słów o negatywnym potencjale, stosującą przemoc. Przygotowanie do takich sytuacji polega na umiejętności radzenia sobie z komunikatami perswazyjnymi, zachowania cierpliwości i nieuleganie prowokacji, rozwiązywania sytuacji kryzysouych, reakcji na przemoc.

Persuazja może mieć różny charakter. Dua typy perswazji - pobudzająca i nakłaniająca - wchodzą w zakres przymusu emocjonalnego wobec adresata. W sytuacji stosowania wobec nas perswazji naruszającej naszą wolność i godność, stosowania psychotechnik, naszą reakcją może być wytworzenie mechanizmu obronnego. Na bazie doświadczenia własnej wolności odbiorca odkrywa, że podlega perswazji, która tę wolność narusza. Mechanizm obronny może przyjąć formę reakcji emocjonalnej ze strony osoby podlegającej przemocy perswazyjnej. Umiejętność reakcji, która nie będzie podobna do przemocy perswadującego, opartej na analizie sytuacji komunikacyjnej i odkryciu charakteru persuazji będzie najlepszym antidotum na tę formę przemocy. Brak wiedzy i umiejętności analitycznych w takiej kryzysowej sytuacji komunikacyjnej zagraża uciągnięciem u sferę przemocy na pozie emocjonalnego oduetu.

Kompetentny odbiorca musi mieć świadomość, że docierające do niego komunikaty mogą mieć założony świadomie lub nieuświadomiony przez nadaucę charakter prowokacyjny. Przykładem celowego prowokowania i uprowadzenia kontrowersji do komunikacji jest trolling ${ }^{19}$. Trolling w sposób manipulacyjny i wyrafinowany uderza w bardzo delikatne struny myślenia człowieka - świat wartości, świat przekonań, ocen rzeczywistości - uprowadzając rodzaj niepokoju podważającego pewność przekonań. Trolling jest inspiracją do negatywnych reakcji wobec innych ludzi. Odbiorca może

\footnotetext{
${ }^{19}$ Por. D. Jachyra, Trollowanie - antyspołeczne zachowania w Internecie, sposoby wykrywania $i$ obrony, „Zeszyty Naukowe Uniwersytetu Szczecińskiego. Studia Informatica” 2011, nr 28, s. 253-261.
} 
ulec prowokacji i podejmować działania wysoce nieracjonalne, kierowane emocjami. Może to skutkować utratą kontroli nad przekazem i jego skutkami. Umiejętnością, która może zaradzić takiej ewentualności, jest kształtowanie zmysłu krytycznego wobec upowszechnianych w przestrzeni publicznej ocen. Zmysł taki pozwala na ocenę wiarygodności przekazów i dostrzeżenie ich ewentualnego prowokacyjnego charakteru. Bardzo często w komentarzach pod artykułami w Internecie, zułaszcza tymi, które dotykają spraw śuiatopoglądowych i politycznych można dostrzec komentarze, które są indywidualną reakcją odbiorców albo noszą znamiona zespolonej strategicznej reakcji tak zwanej fabryki trolli.

Mogą zdarzyć się sytuacje o potencjale przemocy, która została wprowadzona przez czynniki niezależne od uczestników (np. o charakterze społecznym). Umiejętność rozeznania kontekstu komunikacyjnego pozwala w takiej sytuacji w sposób sprawiedliuy ocenić zachowanie osoby, która nie zawiniła. Bardzo użyteczna będzie wiedza o charakterze kontekstu komunikacyjnego oraz jego wpływie na akty komunikowania. Reakcje emocjonalne na nieprzeuidziane sytuacje kryzysowe mogą dotykać najbliższych uczestników komunikowania.

Odbiorca może zostać postawiony u sytuacji, w której jednoznacznie identyfikuje działania werbalne skierowane do niego jako działania przemocowe. Umiejętność rozeznania stanu, w którym stykamy się z takim rodzajem przemocy, na który nie znajdujemy odpowiedzi (nieprzekraczającej zasady stosouności) jest elementem kompetencji na pieruszym, podstawowym etapie. Drugim etapem będzie tu decyzja o uycofaniu się z komunikowania dla dobra odbiorcy i nadawcy. Będzie to przerwanie potencjalnej spirali przemocy już u źródła. Ten aspekt kompetencji uymaga rozeznania prymatu wartości ${ }^{20}$.

\section{Wnioski}

Aby skutecznie przeciudziałać zjawisku przemocy, po pierusze, należy uznać, że wypowiadane słowa, wszelkie działania komunikacyjne, muszą być rozpatrywane z perspektywy etyczności. Inne rozuiązania mogą tylko doraźnie zaradzać kryzysom komunikacyjnym, nie będą jednak długofalowo skuteczne, bo będą miały charakter tylko formalny. Dostrzeżenie zła przemocy, to dostrzeżenie działań odnoszących się do człowieka, a ten uprowadza głębię etyczną. Dlatego warto rozważać na temat dobrego słowa, bo ono ma wartość etyczną. Jak długo nie będziemy rozpatrywać przemocy w kategoriach etycznych, nie będziemy umieli jej przeciudziałać. Kto nie rozumie tego zuiązku, nie może być uznany za osobę kompetentną.

Kompetencje komunikacyjne, ich kształcenie u dzieci i młodzieży oraz nieustanny rozuój u osób dorosłych obejmuje zarówno kategorię skuteczności, jak i stosouności komunikowania. Zasady grzeczności językowej mogą pozostać na płytkim poziomie,

${ }^{20}$ Por. M. Drożdż, Etyka mediów w obronie wartości, Wydawnictuo Naukowe Uniwersytetu Papieskiego Jana Pawła II, Kraków 2019, s. 119. 
jeśli jedyną motywacją ich stosowania będzie uznanie osób przekraczających te zasady za niekulturalne czy pozbawione dobrych manier. Takie wyjaśnienie sensouności stosouności komunikacyjnej będzie niewystarczające. Zasady grzeczności językowej, rozumienie wartości dobrych słów mogą też być rozuijane na poziomie pogłębionym, gdy uczestnik komunikowania nie tylko zna zasady stosowności i wie „jak” się zachować, ale przede uszystkim, gdy wie „dlaczego” i „po co” je stosuje. Podstawową motywacją stosownych zachowań komunikacyjnych winno być poszanowanie partnera jako osoby. Z tego poszanowania, jako konsekwencje, wynikają konkretne realizacje werbalne.

Słowa są tworzywem, które posiada wielką moc. Dobre słowa, które zostały wcześniej scharakteryzowane, służą przezuyciężaniu przemocy i tworzeniu klimatu życzliwości. Słowa dobre, stosowne zachowania komunikacyjne wypełniają przestrzeń porozumiewania, uypierając niestosowne i nieetyczne zachowania słowne, blokując ewentualne fale przemocy, zażegnując zalążki przemocy, niwelując ryzyko jej wystąpienia. Właściuie i głęboko pojmowane kompetencje komunikacyjne stają się antidotum na przemoc.

Apel o rugowanie przemocy z przestrzeni komunikacyjnej jest róunoznaczny z apelem o wzrost poziomu kompetencji komunikacyjnych uczestników aktów komunikacyjnych. Edukacja medialna jest szansą na ograniczenie przemocy w komunikacji na poziomie interpersonalnym i masowym, w różnych jej wymiarach. Kompetencje komunikacyjne u zakresie dobrego słowa są tym ważniejsze, że wypowiedziane słowo przestaje być przez nadaucę kontrolowane. Słowa mogą być nośnikiem przemocy, wyrządzać krzywdę, nawet gdy nie było to zaplanowane przez nadawcę. Rozwój technologii komunikacyjnych i niespotykana nigdy wcześniej w historii łatwość przekazu sprawiają, że współcześnie słowa mają jeszcze większą moc, rozprzestrzeniają się wiralowo, ich negatywny lub pozytywny wydźwięk jest spotęgowany, multiplikowany przez możliwości technologiczne. W tym kontekście tym ważniejsza i pilniejsza uydaje się refleksja nad poziomem i jakością kompetencji komunikacyjnych uczestników procesów porozumiewania się.

\section{Bibliografia}

Bartmiński J., Etyka stowa a potoczny wzorzec komunikacji, http://wuw.rjp.pan.pl/index.php? option=com_content\&view=article\&id=1352\&Itemid=50 (dostęp: 10.07.2019).

Cegieła A., Stowa i ludzie. Wprowadzenie do etyki słowa, Dom Wydawniczy Elipsa, Warszawa 2014.

Drożdż M., Etyka mediów w obronie wartości, Wydawnictwo Naukowe Uniwersytetu Papieskiego Jana Pawła II, Kraków 2019.

Drożdż M., Język nienawiści $w$ dyskursie medialnym, „Acta Universitatis Lodziensis. Folia Litteraria Polonica" 2016, 1 (31), s. 21-32, http://dx.doi.org/10.18778/1505-9057.31.02.

Drożdż M., Osoba i media w prawdzie i uczciwości, Wydawnictuo Petrus, Kraków 2018.

Drożdż M., Osoba i media. Personalistyczny paradygmat etyki mediów, Wydaunictuo Diecezji Tarnouskiej Biblos, Tarnóu 2005. 
Jachyra D., Trollowanie - antyspołeczne zachowania $w$ Internecie, sposoby wykrywania i obrony, „Zeszyty Naukowe Uniwersytetu Szczecińskiego. Studia Informatica” 2011, nr 28, s. 253-261.

Jan Paweł II, Homilia wygłoszona w czasie Mszy św. w Olsztynie, 6 czerwca 1991 roku, [w:] Jan Paweł II, Pielgrzymki do Ojczyzny. Przemówienia i homilie, wyd. 3, Społeczny Instytut Wydawniczy Znak, Kraków 2005.

Jedlecka W., Helios J., Wspótczesne oblicza przemocy. Zagadnienia wybrane, E-Wydaunictuo. Prawnicza i Ekonomiczna Biblioteka Cyfrowa, Wrocław 2017.

Kodeks Etyki Dziennikarskiej SDP, http://sdp.pl/s/kodeks-etyki-dziennikarskiej-sdp (dostęp: 10.07.2019)

Lubkina V., Marzano G., Cyberprzemoc [w:] Zagrożenia cyberprzestrzeni, red. J. Lizut, Wydawnictuo Wyższej Szkoły Pedagogicznej im. Janusza Korczaka, Warszawa 2014, s. 85-98.

Marcyński K., Kompetencja komunikacyjna. Studium medioznawcze, Wydawnictwo Naukowe Uniwersytetu Kardynała Stefana Wyszyńskiego, Warszawa 2017.

Markouski A., Etyka stowa [w:] H. Jadacka, A. Markouski, D. Zdunkiewicz-Jedynak, Poprawna polszczyzna. Hasła problemowe, PWN, Warszawa 2008.

McLuhan M., Zrozumieć media. Przedłużenia człowieka, przeł. N. Szczucka, Warszawa 2004.

Przybylska R., Wstęp do nauki o języku polskim, Wydawnictuo Literackie, Kraków 2003.

Rozmarynouska K., Performatywność języka a powinność moralna, „Studia Philosophiae Christianae" 2018, t. 54, nr 2, s. 129-146.

Słupek L., Bartoszcze R., Kompetencja komunikacyjna [w:] Słownik terminologii medialnej, red. W. Pisarek, TAiWPN Universitas, Kraków 2008. 